Article

\title{
Assessment of Different Metal Screw Joint Parameters by Using Multiple Criteria Analysis Methods
}

\author{
Audrius Čereška ${ }^{1}$, Askoldas Podviezko ${ }^{2}$ (D) and Edmundas Kazimieras Zavadskas ${ }^{3, * \text { (D) }}$ \\ 1 Department of Mechanical and Material Engineering, Vilnius Gediminas Technical University, \\ Basanavičiaus str. 28, LT-03324 Vilnius, Lithuania; audrius.cereska@vgtu.lt \\ 2 Department of Economics Engineering, Vilnius Gediminas Technical University, Saulètekio al. 11, \\ LT-10223 Vilnius, Lithuania; askoldas@gmail.com \\ 3 Research Institute of Sustainable Construction, Vilnius Gediminas Technical University, Saulètekio al. 11, \\ LT-10223 Vilnius, Lithuania \\ * Correspondence: edmundas.zavadskas@vgtu.lt; Tel.: +370-5-2744-910
}

Received: 13 March 2018; Accepted: 30 April 2018; Published: 4 May 2018

\begin{abstract}
This study compares screw joints made of different materials, including screws of different diameters. For that purpose, 8, 10, 12, 14, $16 \mathrm{~mm}$ diameter steel screws and various parts made of aluminum $(\mathrm{Al})$, steel $(\mathrm{Stl})$, bronze $(\mathrm{Brz})$, cast iron $(\mathrm{CI})$, copper $(\mathrm{Cu})$ and brass $(\mathrm{Br})$ are considered. Multiple criteria decision making (MCDM) methods such as evaluation based on distance from average solution (EDAS), simple additive weighting (SAW), technique for order of preference by similarity to ideal solution (TOPSIS) and complex proportional assessment (COPRAS) are utilized to assess reliability of screw joints also considering cost issues. The entropy, criterion impact loss (CILOS) and integrated determination of objective criteria weights (IDOCRIW) methods are utilized to assess weights of decision criteria and find the best design alternative. Numerical results confirm the validity of the proposed approach.
\end{abstract}

Keywords: civil engineering; bolt joint; parameters; MCDM; entropy; TOPSIS; EDAS; CILOS; IDOCRIW

\section{Introduction}

Screw joints are widely used [1-4] in cars, trucks, marine engines, compressors and generators, railway track construction, aviation, industrial fans, refrigeration equipment, machine tools, presses, instrumentation, conveyors, all types of mining machines, etc. [5-10]. The most important concerns for screw joints performance are (i) relaxation caused by vibration; and (ii) relaxation caused by dynamic loading, fatigue or corrosion [5]. The mechanical behavior of screw joints subject to transverse loading was investigated in [6-8]. Bhattacharya [9] showed that transverse or shear loads are the main cause of vibration-induced loosening. In [10], it is shown that, at high loads, there is an appropriate ratio between screw length and diameter to prevent sliding between threads. The theoretical model of screw joint behavior of [11,12] introduced a few more parameters besides reciprocating and rotational degrees of freedom and considered technical characteristics of connecting elements. The effect of contact pressure distribution was analyzed in [13]. In [14], it was found that a screw joint is relaxed at smaller loads than expected due to the sliding of contact area. Zapico-Valle [15] presented an experimental validation of a new statistical process control feature for damage detection. In [16,17], screw joints excited by vibrations of different frequencies were analyzed. Laser technologies were used in [18-20]. Izumi and Yokoyama et al. [21,22] analyzed relaxation of screw joints with spring washers using the finite element method. In [23-32], loosening of screws of different types, geometry, and materials, was investigated by considering various clamping forces and temperatures: relaxation rate was related to clamping force. Friction between joint parts were investigated in $[31,32]$ and 
connection reliability was related to friction. In [33,34], continuous wavelet analysis of mode shapes was utilized for damage detection.

Theoretical analyses and experimental tests serve to assess reliability of screw joints, clarifying relationships between the cost of the junction and the technical parameters of the joint. For this reason, multiple criteria decision-making (MCDM) analysis was carried out in [35-40]. Various MCDM methods were successfully utilized in engineering problems. For example, the analytical hierarchy process (AHP) was used for steel bridges [41,42], energy absorption parts [43] and cold-formed thin-walled steel structures [44]. The TOPSIS (technique for order of preference by similarity to ideal solution) method was applied to steel constructions [45].

Welding processes were evaluated with fuzzy logic [46]. Laser cutting technological parameters were selected with AHP-TOPSIS [47]. Thin-walled structures were evaluated with the COPRAS (complex proportional assessment) method [48-54]. A hybrid method, AHP-COPRAS-G, was used for designing cold-formed steel structures [55]. MCDM methods helped to select materials for a cutting tool [56], structural materials [57-60], machine tools for changing production flow [61].

In this study, classical MCDM methods such as EDAS (evaluation based on distance from average solution), SAW (simple additive weighting), TOPSIS and COPRAS will be used for evaluating performance of screw joints with respect to technical and economic parameters. Furthermore, recently developed methods for rating the importance of decision making criteria, such as CILOS (criterion impact loss) and IDOCRIW (integrated determination of objective criteria weights), will be used in the general context of a MCDM framework.

\section{Subject of the Study}

This study focusses on screw joints like that shown in Figure 1 as they are the most popular elements used in construction. We investigate behavior of a single joint, leaving investigation of more complex structures for future studies. The single-joint case is relevant, however, because a rather common approach in structural design and verification is to consider the most loaded screw of the connection.

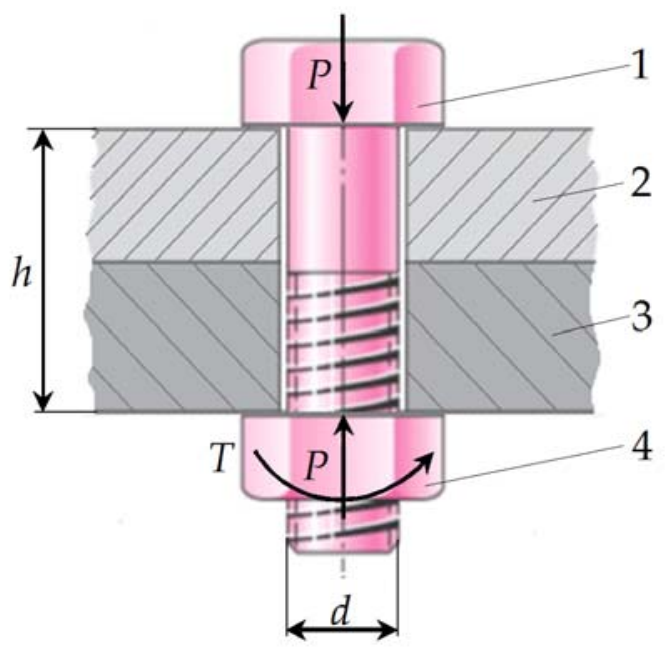

Figure 1. Screw joint: 1 -screw, 2, 3-joint element; 4-screw-nut, $h$-thickness of joint elements, $d$-screw diameter, $P$-clamping force, $T$-torque.

In this study, we attempted to evaluate widely used screws M8, M10, M12, M14, M16 in civil and mechanical engineering for connecting flat elements made of different materials. The connecting details are made of $\mathrm{Stl}, \mathrm{CI}, \mathrm{Al}, \mathrm{Brz}, \mathrm{Br}$ and $\mathrm{Cu}$. Parameters of the compounds used for calculations are presented in Table 1. 
Table 1. Parameters of screw joints.

\begin{tabular}{|c|c|c|c|c|c|c|c|}
\hline Row No. & $\begin{array}{c}\text { Material Elastic } \\
\text { Coefficient } E, \\
\text { MPa }\end{array}$ & $\begin{array}{c}\text { Screw } \\
\text { Diameter, } \\
d, \mathrm{~mm}\end{array}$ & $\begin{array}{c}\text { Friction } \\
\text { Coefficient } \\
\text { between Screw } \\
\text { and Element, } f_{1}\end{array}$ & $\begin{array}{c}\text { Friction } \\
\text { Coefficient } \\
\text { between } \\
\text { Elements, } f_{2}\end{array}$ & $\begin{array}{l}\text { Clamping } \\
\text { Force, } P, \mathbf{N}\end{array}$ & $\begin{array}{c}\text { Torque, } T, \\
\mathrm{~N} \cdot \mathrm{m}\end{array}$ & $\begin{array}{c}\text { Average } \\
\text { Price, } €\end{array}$ \\
\hline 1 & $\mathrm{Al}, 7 \times 10^{4}$ & \multirow{4}{*}{$8-16$} & 0.4 & 0.7 & \multirow{4}{*}{$4629-19,123$} & \multirow{4}{*}{$7.83-63.33$} & $1.40-5.43$ \\
\hline 2 & Stl, $2.1 \times 10^{5}$ & & 0.16 & 0.16 & & & $0.25-0.97$ \\
\hline 3 & $\mathrm{Brz}, 10^{5}$ & & 0.13 & 0.19 & & & $4.82-18.72$ \\
\hline 6 & $\mathrm{Br}, 1.2 \times 10^{5}$ & & 0.35 & 0.82 & & & $4.05-14.42$ \\
\hline
\end{tabular}

\section{Theoretical Analysis of a Screw Joint}

Different requirements for material selections and construction must be satisfied in screw joint technology. If the joint can be disassembled during operation, joint parts are usually connected by screws. The definition of a joint's strength depends on the operating loads. Slipping between connecting parts is not possible if external load is perpendicular to the bolt's axis. The maximum clamping force that can be transmitted by a screw joint is [62]

$$
P=0.6 P\left(f_{1}+f_{2}\right),
$$

where 0.6 is the average value of the knockdown factor; $P$ is the clamping force (expressed in Newtons); $f_{1}$ is the coefficient of friction between the nut and the component; $f_{2}$ is the coefficient of friction between the joint components.

Another requirement for reliability of the threaded connection is to ensure a good contact between joint components. The possibility that joint dismantles depends on the flexibility of screws and joint components. The separation force is [62]

$$
F_{\mathrm{at}}=\frac{P}{v(1-\chi)^{\prime}}
$$

where $\chi=\frac{\lambda_{d}}{\lambda_{d}+\lambda_{v}} ; \lambda_{d}$ is flexibility of joint components, $\lambda_{v}$ is flexibility of screw stretching.

If the thickness of joint components is close to the screw's diameter, it holds, $\lambda_{\mathrm{d}}=\frac{0.82}{E_{\mathrm{d}}}, \lambda_{v}=\frac{1.27}{E_{\mathrm{p}}}$, where $E_{\mathrm{d}}$ and $E_{\mathrm{p}}$, respectively, are the values of elastic modulus of joint parts and screw (usually, steel for the latter).

When the external load is oriented perpendicular to the bolt's axis, the rationale of the screw joint is the following: the equality between the bolt's resistance to cutting and resistance of the joint components to crumpling. The details are crumpled when the transverse force exceeds the permissible shear force (1). Consequently, the minimum thickness of the joint components is [62]

$$
h_{\min }=\frac{F_{\mathrm{S}}}{\sigma_{\mathrm{adm}, \mathrm{q}}},
$$

where $\sigma_{\mathrm{adm}, \mathrm{ql}}$ is the adhesion strength of joint parts.

The joint can be preliminarily designed using the following equation [62]:

$$
\sigma_{\mathrm{adm}, \mathrm{ql}}=0.45 \sigma_{\mathrm{adm}}
$$

where $\sigma_{\mathrm{adm}}$ is the allowable tensile limit of the material.

Screw joints are also used for joining components subject to bending. Due to the normal tensions in the joint parts directed in opposite directions, the joint components can push one another. The maximum bending stress in case of non-slipping of the parts is [62] 


$$
\sigma_{\max }=\frac{6 M_{1}}{b h^{2}}
$$

where $M_{1}$ is the bending moment working on the anchorage, $b$ is the width of the joint components, $h$ is the total thickness of the joint components.

When the joint components are of the same thickness $(h / 2)$, the following relationship can be used for each detail [62]:

$$
F_{\mathrm{t}} \leq \frac{6}{4} \frac{M_{1}}{h} .
$$

The slipping of joint parts does not occur if (7) holds [62]:

$$
F_{\mathrm{t}} \leq F_{\mathrm{f}}=P f_{2},
$$

where $P$ and $f_{2}$ are those defined for Equation (1).

The condition of prevention of slipping of the components can be expressed by the relative internal bending stress divided by the integral thickness of the parts of the joint [62]:

$$
\frac{M_{1}}{h}=\frac{4 P f_{2}}{9}\left(\frac{\mathrm{Nm}}{\mathrm{mm}}\right) .
$$

The strength of the joint is ensured by the tightening force created by the screw in the nut. Tightening strength of the joint $P$ is determined by the allowable stress of the screw material. Then, the torque is defined as [62]

$$
T=0.5 \times 10^{-3} \operatorname{Pd}\left(\frac{1}{\pi} \times \frac{s}{d}+\frac{D}{d} f_{1}+\frac{d_{\mathrm{m}}}{d} f_{3}\right),
$$

where $d$ is the diameter of the thread; $s$ is the step of the thread; $D$ is the diameter of the nut of the supporting surface $(D=1.3 d) ; d_{\mathrm{m}}$ is the average diameter of the thread; the coefficient of friction $f_{1}$ between the nut and the detail (when both are made of steel) was accepted to be $0.16 ; f_{3}=\frac{f_{1}}{\cos 30^{\circ}}$ is the coefficient of friction between the screw and the nut of the threaded surfaces.

Output quantities of Equations (1)-(9) provide entries for the decision matrix (10).

\section{The Multiple Criteria Evaluation}

Some multiple criteria methods were used for evaluating the combinations of technical and economic parameters of screw joints: EDAS [63], SAW [64], TOPSIS [64] and COPRAS [65]. The following methods for assessing importance weight of criteria were used: entropy, the criterion loss method CILOS for the determination of weighting criteria and the integrating IDOCRIW method [66]. Combination of various methods with different logic for making quantitative evaluations allows smoothing over distortions introduced by intrinsic data transformations in each MCDM method [67-70].

\subsection{The EDAS Method}

The EDAS method discerns alternatives based on the distance from the average solution [63]. Two measures for calculating the cumulative criterion of the method are used. The first measure is the positive distance from the average solution (PD), and the second is the negative distance from the average solution (ND). Evaluation of the alternatives is made according to higher values of PD and lower values of ND. The steps for using the EDAS method are as follows:

Step 1: The decision matrix $(R)$ is constructed:

$$
R=\left\|r_{i j}\right\|
$$

The matrix is presented in Table 2. This decision matrix will also be used in other MCDM methods. 
Step 2: The vector of weights is created:

$$
\Omega=\left(\omega_{j}\right)
$$

where $i=1,2, \ldots, n ; j=1,2, \ldots, m ; m$ - the number of criteria; $n$-the number of options compared [63].

Step 3: The average solution is calculated:

$$
\mathrm{AV}_{j}=\sum_{i=1}^{n} r_{i j} / n
$$

Step 4: Positive distances from average (PD) and the negative distances from the average solution (ND) are calculated for the maximizing criteria:

$$
\begin{aligned}
\mathrm{PD}_{i j} & =\frac{\max \left(0,\left(r_{i j}-\mathrm{AV}_{j}\right)\right)}{\mathrm{AV}_{j}}, \\
\mathrm{ND}_{i j} & =\frac{\max \left(0,\left(\mathrm{AV}_{j}-r_{i j}\right)\right)}{\mathrm{AV}_{j}},
\end{aligned}
$$

and for the minimizing criteria:

$$
\begin{aligned}
\mathrm{PD}_{i j} & =\frac{\max \left(0,\left(\mathrm{AV}_{j}-r_{i j}\right)\right)}{\mathrm{AV}_{j}}, \\
\mathrm{ND}_{i j} & =\frac{\max \left(0,\left(r_{i j}-\mathrm{AV}_{j}\right)\right)}{\mathrm{AV}_{j}},
\end{aligned}
$$

where $\mathrm{PD}_{i j}$ and $\mathrm{ND}_{i j}$ denote the positive and negative distance of the $i$-th alternative from the average solution in terms of $j$-th criterion, respectively.

Step 5: The weighted sum of PD and ND is calculated for all alternatives:

$$
\begin{aligned}
\mathrm{SP}_{i} & =\sum_{j=1}^{m} \omega_{j} \cdot \mathrm{PD}_{i j}, \\
\mathrm{SN}_{i} & =\sum_{j=1}^{m} \omega_{j} \cdot \mathrm{ND}_{i j},
\end{aligned}
$$

where $\omega_{j}$ is the weight of $j$-th criterion.

Step 6: Values of SP and SN are normalized for all alternatives:

$$
\begin{gathered}
\mathrm{NSP}_{i}=\frac{\mathrm{SP}_{i}}{\max _{i} \mathrm{SP}_{i}}, \\
\mathrm{NSN}_{i}=1-\frac{\mathrm{SN}_{i}}{\max _{i} \mathrm{SN}_{i}} .
\end{gathered}
$$

Step 7: The cumulative criterion AS of the EDAS method is calculated for all alternatives:

$$
\mathrm{AS}_{i}=\frac{1}{2}\left(\mathrm{NSP}_{i}+\mathrm{NSN}_{i}\right)
$$

where $0 \leq \mathrm{AS}_{i} \leq 1$.

\subsection{The SAW Method}

The basic idea behind the MCDM methods is to combine values of criteria and weights to obtain a single cumulative criterion for evaluation of the method. The most common example is the SAW method [64], where the method's cumulative criterion $S_{i}$ is calculated as 


$$
S_{i}=\sum_{j=1}^{m} w_{j} \widetilde{r}_{i j^{\prime}}
$$

where $w_{j}$ are weights of the $j$-th criterion and $\widetilde{r}_{i j}$ are normalized (dimensionless) values of the $j$-th criterion for the $i$-th alternative:

$$
\widetilde{r}_{i j}=\frac{r_{i j}}{\sum_{i=1}^{n} r_{i j}} .
$$

\subsection{The TOPSIS Method}

The TOPSIS method is characterized by the use of vector normalization [64] and by its specific features described in [71] which allow using it for making an evaluation of a single alternative:

$$
\widetilde{r}_{i j}=\frac{r_{i j}}{\sqrt{\sum_{i=1}^{n} r_{i j}^{2}}}(i=1, \ldots, n ; j=1, \ldots, m),
$$

where $\widetilde{r}_{i j}$ are normalized values of $j$-th criterion for $i$-th alternative.

The best alternative $V^{*}$ and the worst alternative $V^{-}$are determined as

$$
\begin{gathered}
V^{*}=\left\{V_{1}^{*}, V_{2}^{*}, \ldots, V_{m}^{*}\right\}=\left\{\left(\max _{i} \omega_{j} \widetilde{r}_{i j} / j \in J_{1}\right),\left(\min _{i} \omega_{j} \widetilde{r}_{i j} / j \in J_{2}\right)\right\}, \\
V^{-}=\left\{V_{1}^{-}, V_{2}^{-}, \ldots, V_{m}^{-}\right\}=\left\{\left(\min _{i} \omega_{j} \widetilde{r}_{i j} / j \in J_{1}\right),\left(\max _{i} \omega_{j} \widetilde{r}_{i j} / j \in J_{2}\right)\right\},
\end{gathered}
$$

where $J_{1}$ is a set of indices of the maximized criteria, $J_{2}$ is a set of indices of the minimized criteria.

The distance $D_{i}^{*}$ of every considered alternative to the ideal (best) solution and its distance $D_{i}^{-}$from the worst solution are calculated (27):

$$
\begin{aligned}
& D_{i}^{*}=\sqrt{\sum_{j=1}^{m}\left(\omega_{j} \widetilde{r}_{i j}-V_{j}^{*}\right)^{2}}, \\
& D_{i}^{-}=\sqrt{\sum_{j=1}^{m}\left(\omega_{j} \widetilde{r}_{i j}-V_{j}^{-}\right)^{2}} .
\end{aligned}
$$

The criterion $C_{i}^{*}$ of the TOPSIS method is determined:

$$
C_{i}^{*}=\frac{D_{i}^{-}}{D_{i}^{*}+D_{i}^{-}}(i=1, \ldots, n)
$$

$\left(0 \leq C_{i}^{*} \leq 1\right)$.

The largest value of the criterion $C_{i}^{*}$ corresponds to the best alternative.

\subsection{The COPRAS Method}

The $Z_{i}$ criterion of the COPRAS method is determined as [65]

$$
Z_{i}=S_{+i}+\frac{\sum_{i=1}^{n} S_{-i}}{S_{-i} \sum_{i=1}^{n} \frac{1}{S_{-i}}}
$$


where $S_{+i}=\sum_{j=1}^{m} \omega_{j} \widetilde{r}_{+i j}$ is the sum of the weighted values of the maximized criteria $\widetilde{r}_{+i j}$, $S_{-i}=\sum_{j=1}^{m} \omega_{j} \widetilde{r}_{-i j}$. The same applies for the minimizing criteria.

In order to compute values of the $Z_{i}$ criterion, input data are normalized using Equation (23).

\subsection{Methods for Determining the Weights of the Criteria}

\subsubsection{The Entropy Method}

The entropy method was proposed by Claude E. Shannon in [72]. Entropy weights are defined as follows [64,66]:

1. The values of criteria are normalized as

$$
\widetilde{r}_{i j}=\frac{r_{i j}}{\sum_{i=1}^{n} r_{i j}} .
$$

2. The entropy level of each criterion is calculated as follows:

$$
E_{j}=-\frac{1}{\ln n} \sum_{i=1}^{n} \widetilde{r}_{i j} \cdot \ln \widetilde{r}_{i j},\left(j=1,2, \ldots, m ; 0 \leq E_{j} \leq 1\right) .
$$

3. The variation level of each criterion is calculated:

$$
d_{j}=1-E_{j}
$$

4. Entropy weights are calculated by normalizing values $d_{j}$ :

$$
W_{j}=\frac{d_{j}}{\sum_{j=1}^{m} d_{j}} .
$$

Entropy weights reflect the structure of data revealing the degree of non-homogeneity of data. Weights of homogeneous data (when the values of the criteria do not differ considerably) for a certain criterion obtained by the entropy method [66] should be close to zero and would have only a minor influence on the results of evaluation. The largest weight of a criterion obtained from entropy method corresponds to the criterion with the highest rate of data inhomogeneity.

\subsubsection{Method of Criterion Impact Loss-CILOS}

In this method, impact loss is measured and objective weights are determined based on this measurement $[60,73]$. The method evaluates the loss of impact for each criterion until one of the remaining criteria acquires the optimum - the maximum or the minimum value. The algorithm of the method, formalization, description and application has been presented in [66]. The logic of the method of criteria significance loss, its basic ideas, stages and implementation steps are as follows.

The method can be applied only to the maximizing criteria, therefore minimizing criteria are to be transformed into the maximizing ones. There could be different transformations for this purpose. The inverse transformation was applied:

$$
\bar{r}_{i j}=\frac{\min _{i} r_{i j}}{r_{i j}}
$$

The new matrix with transformed minimizing values and the same maximizing values is denoted as $X=\left\|x_{i j}\right\|$. The maximum values for each column (i.e., each criterion) are calculated: $x_{j}=\max _{i} x_{i j}=x_{k_{j}}$, where $k_{j}$ is the number of the row of $j$-th column hosting the largest value, is obtained. 
A square matrix $A=\left\|a_{i j}\right\|$ is formed from values of $k_{j}$ rows of the $X$ matrix. $x_{k_{i} j}$ correspond to the maximum values of $i$-th criterion: $a_{j j}=x_{j}, a_{i j}=x_{k_{i}}(i, j=1,2, \ldots, m ; m-$ number of criteria).

A matrix $P=\left\|p_{i j}\right\|$ of the relative losses is created:

$$
p_{i j}=\frac{x_{j}-a_{i j}}{x_{j}} .\left(p_{i i}=0 ; i, j=1,2, \ldots, m\right) .
$$

Elements $p_{i j}$ of $P$ matrix show the loss of alternative relatively to the $j$-th criterion, if the $i$-th criterion is selected as the best.

Weights $q=\left(q_{1}, q_{2}, \ldots, q_{m}\right)$ can be determined by solving the linear system:

$$
F \cdot q=0
$$

where, the matrix $F$ is as follows:

$$
F=\left(\begin{array}{cccc}
-\sum_{i=1}^{m} p_{i 1} & p_{12} & \cdots & p_{1 m} \\
p_{21} & -\sum_{i=1}^{m} p_{i 2} & \cdots & p_{2 m} \\
\vdots & \vdots & \ddots & \vdots \\
p_{m 1} & p_{m 2} & \cdots & -\sum_{i=1}^{m} p_{i m}
\end{array}\right)
$$

The method based on the criterion significance loss offsets the drawback of the entropy method. Thus, when the values of a criterion do not considerably differ, the element $s p_{i j}$ of the matrix $P$ of relative loss of criterion impact (36) becomes close to zero, while the respective criterion weight increases and has a strong impact on the evaluation. If data are homogeneous, when values of a criterion are similar for all alternatives, all relative losses of the criterion, as well as its total loss, become close to zero. Consequently, the linear system of Equation (37) loose of significance because one column of elements in matrix $P$ is close to zero.

\subsubsection{Aggregate Objective Weights (IDOCRIW Method)}

Using the idea of comprising different weights of significance obtained by different methods [64,74,75], the entropy weights $W_{j}[64]$, and weights $q_{j}$ of criteria impact loss [74] into a single overall weight, the ultimate weights $\omega_{j}$ for the evaluation are obtained:

$$
\omega_{j}=\frac{q_{j} W_{j}}{\sum_{j=1}^{m} q_{j} W_{j}}
$$

The method of obtaining such ultimate weights is called Integrated determination of objective criteria weights (IDOCRIW) [66].

These weights incorporate both deviation of particular values of criteria (entropy characteristic) and with relative losses of impact (36). Therefore, extreme possible values obtained by the entropy method are compensated by the CILOS method.

Calculated weights of the entropy and criteria loss of impact are combined into aggregated weights and then are used in multiple criteria assessment for ranking options and for selecting the best alternative.

\section{Results and Discussion}

\subsection{Results of Theoretical Analysis of Screw Joints}

Results of theoretical analysis carried out on screw joints are presented in Table 2. The values listed in the table are obtained from Equations (1)-(9). 
Table 2. Results of evaluation of screw joints.

\begin{tabular}{|c|c|c|c|c|c|c|c|c|c|c|c|}
\hline Trial & $\begin{array}{l}\text { Young's } \\
\text { Modulus } E \\
\text { MPa }\end{array}$ & $\begin{array}{l}\text { Screw } \\
\text { Diameter, } \\
d, \mathrm{~mm}\end{array}$ & $\begin{array}{c}\text { Friction } \\
\text { Coefficient } \\
\text { between Screw } \\
\text { and Elements, } f_{1}\end{array}$ & $\begin{array}{c}\text { Friction } \\
\text { Coefficient } \\
\text { between } \\
\text { Elements, } f_{2} \\
\end{array}$ & $\begin{array}{l}\text { Clamping } \\
\text { Force } P, \mathrm{~N}\end{array}$ & $\begin{array}{l}\text { Torque, } \\
T, \mathrm{~N} \cdot \mathrm{m}\end{array}$ & $\begin{array}{c}\text { Limit } \\
\text { Shear } \\
\text { Force } F_{\mathrm{s}}, \mathrm{N}\end{array}$ & $\begin{array}{c}\text { Limit } \\
\text { Abruption } \\
\text { Force } F_{\text {at }}, \mathrm{N}\end{array}$ & $\begin{array}{c}\text { Minimal Thickness } \\
\text { of Connected } \\
\text { Elements, } h, \mathrm{~mm}\end{array}$ & $\begin{array}{c}\text { Limit Relative } \\
\text { Bending Stress, } \\
\text { Nm/mm }\end{array}$ & $\begin{array}{c}\text { Averag } € \\
\text { Price, } €\end{array}$ \\
\hline & & & $\omega_{1}$ & $\omega_{2}$ & & & $\omega_{3}$ & $\omega_{4}$ & $\omega_{5}$ & $\omega_{6}$ & $\omega_{7}$ \\
\hline 1 & $\mathrm{Al}, 7 \times 10^{4}$ & \multirow{6}{*}{8} & 0.4 & 0.7 & \multirow{6}{*}{4629} & \multirow{6}{*}{7834} & 3055 & 6827 & 9.93 & 1.851 & 1.40 \\
\hline 2 & Stl, $2.1 \times 10^{5}$ & & 0.16 & 0.16 & & & 889 & 5904 & 0.398 & 0.329 & 0.25 \\
\hline 3 & Brz, $10^{5}$ & & 0.13 & 0.19 & & & 807 & 6341 & 1.64 & 0.329 & 4.82 \\
\hline 4 & $\mathrm{CI}, 2.1 \times 10^{5}$ & & 0.3 & 0.5 & & & 2221 & 5904 & 4.11 & 1.027 & 0.27 \\
\hline 5 & $\mathrm{Cu}, 1.2 \times 10^{5}$ & & 0.45 & 0.8 & & & 3471 & 7035 & 4.38 & 1.643 & 6.25 \\
\hline 6 & $\mathrm{Br}, 1.2 \times 10^{5}$ & & 0.35 & 0.82 & & & 3523 & 4903 & 1.99 & 1.687 & 4.05 \\
\hline 1 & $\mathrm{Al}, 7 \times 10^{4}$ & \multirow{6}{*}{10} & 0.4 & 0.7 & \multirow{6}{*}{7423} & \multirow{6}{*}{15,663} & 4899 & 10,492 & 12.73 & 2.968 & 2.46 \\
\hline 2 & Stl, $2.1 \times 10^{5}$ & & 0.16 & 0.16 & & & 1425 & 9427 & 0.51 & 0.527 & 0.44 \\
\hline 3 & Brz, $10^{5}$ & & 0.13 & 0.19 & & & 1291 & 9427 & 2.10 & 0.527 & 8.49 \\
\hline 4 & $\mathrm{CI}, 2.1 \times 10^{5}$ & & 0.3 & 0.5 & & & 3563 & 9427 & 5.27 & 1.647 & 0.48 \\
\hline 5 & $\mathrm{Cu}, 1.2 \times 10^{5}$ & & 0.45 & 0.8 & & & 5567 & 11,283 & 5.62 & 2.635 & 11.0 \\
\hline 6 & $\mathrm{Br}, 1.2 \times 10^{5}$ & & 0.35 & 0.82 & & & 5611 & 7861 & 2.55 & 2.710 & 7.13 \\
\hline 1 & $\mathrm{Al}, 7 \times 10^{4}$ & \multirow{6}{*}{12} & 0.4 & 0.7 & \multirow{6}{*}{10,008} & \multirow{6}{*}{25,220} & 6605 & 14,752 & 14.30 & 3.113 & 3.75 \\
\hline 2 & Stl, $2.1 \times 10^{5}$ & & 0.16 & 0.16 & & & 1921 & 12,710 & 0.576 & 0.71 & 0.67 \\
\hline 3 & Brz, $10^{5}$ & & 0.13 & 0.19 & & & 1741 & 12,710 & 2.36 & 0.710 & 12.93 \\
\hline 4 & CI, $2.1 \times 10^{5}$ & & 0.3 & 0.5 & & & 4804 & 12,710 & 5.92 & 2.22 & 0.73 \\
\hline 5 & $\mathrm{Cu}, 1.2 \times 10^{5}$ & & 0.45 & 0.8 & & & 7506 & 15,212 & 6.31 & 3.552 & 16.75 \\
\hline 6 & $\mathrm{Br}, 1.2 \times 10^{5}$ & & 0.35 & 0.82 & & & 7026 & 10,060 & 2.87 & 3.643 & 10.85 \\
\hline 1 & $\mathrm{Al}, 7 \times 10^{4}$ & \multirow{6}{*}{14} & 0.4 & 0.7 & \multirow{6}{*}{14,362} & \multirow{6}{*}{42,124} & 9479 & 21,169 & 17.60 & 4.446 & 4.98 \\
\hline 2 & Stl, $2.1 \times 10^{5}$ & & 0.16 & 0.16 & & & 2757 & 18,240 & 0.709 & 1.019 & 0.89 \\
\hline 3 & $\mathrm{Brz}, 10^{5}$ & & 0.13 & 0.19 & & & 2498 & 18,239 & 2.91 & 1.0197 & 17.18 \\
\hline 4 & $\mathrm{CI}, 2.1 \times 10^{5}$ & & 0.3 & 0.5 & & & 6862 & 18,240 & 7.29 & 3.188 & 0.98 \\
\hline 5 & $\mathrm{Cu}, 1.2 \times 10^{5}$ & & 0.45 & 0.8 & & & 10,771 & 21,830 & 7.77 & 5.098 & 22.25 \\
\hline 6 & $\mathrm{Br}, 1.2 \times 10^{5}$ & & 0.35 & 0.82 & & & 10,082 & 15,209 & 3.53 & 5.228 & 14.42 \\
\hline 1 & $\mathrm{Al}, 7 \times 10^{4}$ & \multirow{6}{*}{16} & 0.4 & 0.7 & \multirow{6}{*}{19,123} & \multirow{6}{*}{63,335} & 12,621 & 28,187 & 20.51 & 5.947 & 5.43 \\
\hline 2 & Stl, $2.1 \times 10^{5}$ & & 0.16 & 0.16 & & & 3672 & 24,286 & 0.826 & 1.358 & 0.97 \\
\hline 3 & $\mathrm{Brz}, 10^{5}$ & & 0.13 & 0.19 & & & 3327 & 26,007 & 3.39 & 1.357 & 18.72 \\
\hline 4 & $\mathrm{CI}, 2.1 \times 10^{5}$ & & 0.3 & 0.5 & & & 9179 & 24,286 & 8.49 & 4.245 & 1.07 \\
\hline 5 & $\mathrm{Cu}, 1.2 \times 10^{5}$ & & 0.45 & 0.8 & & & 13,842 & 39,641 & 9.05 & 6.788 & 24.25 \\
\hline 6 & $\mathrm{Br}, 1.2 \times 10^{5}$ & & 0.35 & 0.82 & & & 14,024 & 20,251 & 4.11 & 6.960 & 14.42 \\
\hline
\end{tabular}




\subsection{Assessment of Results and Analysis}

The results of theoretical evaluation of screw joints (Table 2) are analyzed using multiple criteria analytical methods: EDAS, TOPSIS, COPRAS and SAW. All variants are evaluated twice: using seven criteria (with price) and using six criteria (without price). All calculations are performed with the aggregate IDOCRIW weights.

The results obtained using all seven criteria are presented in Tables 3-7.

The weights of decision criteria resulting from the entropy method are computed with Equations (31)-(34). They are presented in Table 3.

Table 3. Weights of decision criteria determined with the entropy method.

\begin{tabular}{cccccccc}
\hline \multirow{2}{*}{ Screw Diameter, $\boldsymbol{d}, \mathbf{m m}$ Weights } \\
\cline { 2 - 8 } & $\boldsymbol{\omega}_{\mathbf{1}}$ & $\boldsymbol{\omega}_{\mathbf{2}}$ & $\boldsymbol{\omega}_{\mathbf{3}}$ & $\boldsymbol{\omega}_{\mathbf{4}}$ & $\boldsymbol{\omega}_{\mathbf{5}}$ & $\boldsymbol{\omega}_{\mathbf{6}}$ & $\boldsymbol{\omega}_{\mathbf{7}}$ \\
\hline 8 & 0.067 & 0.119 & 0.105 & 0.005 & 0.256 & 0.139 & 0.310 \\
10 & 0.067 & 0.119 & 0.105 & 0.005 & 0.256 & 0.139 & 0.309 \\
12 & 0.068 & 0.120 & 0.103 & 0.007 & 0.259 & 0.130 & 0.314 \\
14 & 0.068 & 0.120 & 0.103 & 0.005 & 0.259 & 0.130 & 0.314 \\
16 & 0.067 & 0.119 & 0.102 & 0.019 & 0.256 & 0.128 & 0.310 \\
\hline
\end{tabular}

The weights of decision criteria resulting from the CILOS method are computed with Equations (35)-(38). They are presented in Table 4.

Table 4. Weights of decision criteria determined with the criterion impact loss (CILOS) method.

\begin{tabular}{cccccccc}
\hline \multirow{2}{*}{ Screw Diameter, $\boldsymbol{d}, \mathbf{m m}$} & \multicolumn{7}{c}{ Weights } \\
\cline { 2 - 8 } & $\boldsymbol{\omega}_{\mathbf{1}}$ & $\boldsymbol{\omega}_{\mathbf{2}}$ & $\boldsymbol{\omega}_{\mathbf{3}}$ & $\boldsymbol{\omega}_{\mathbf{4}}$ & $\boldsymbol{\omega}_{\mathbf{5}}$ & $\boldsymbol{\omega}_{\mathbf{6}}$ & $\boldsymbol{\omega}_{\mathbf{7}}$ \\
\hline 8 & 0.116 & 0.158 & 0.172 & 0.224 & 0.107 & 0.123 & 0.101 \\
10 & 0.117 & 0.157 & 0.174 & 0.214 & 0.108 & 0.127 & 0.102 \\
12 & 0.118 & 0.170 & 1.127 & 0.204 & 0.110 & 0.170 & 0.100 \\
14 & 0.117 & 0.166 & 0.125 & 0.217 & 0.109 & 0.166 & 0.099 \\
16 & 0.120 & 0.172 & 0.190 & 0.105 & 0.127 & 0.172 & 0.113 \\
\hline
\end{tabular}

The weights of decision making criteria resulting from the IDOCRIW method are computed with Equation (39) and are presented in Table 5.

Table 5. Weights of decision criteria determined with the integrated determination of objective criteria weights (IDOCRIW) method.

\begin{tabular}{cccccccc}
\hline \multirow{2}{*}{ Screw Diameter, $\boldsymbol{d}, \mathbf{m m}$} & $\mathbf{9}$ Weights \\
\cline { 2 - 8 } & $\boldsymbol{\omega}_{\mathbf{1}}$ & $\boldsymbol{\omega}_{\mathbf{2}}$ & $\boldsymbol{\omega}_{\mathbf{3}}$ & $\boldsymbol{\omega}_{\mathbf{4}}$ & $\boldsymbol{\omega}_{\mathbf{5}}$ & $\boldsymbol{\omega}_{\mathbf{6}}$ & $\boldsymbol{\omega}_{\mathbf{7}}$ \\
\hline 8 & 0.064 & 0.154 & 0.149 & 0.010 & 0.225 & 0.140 & 0.258 \\
10 & 0.064 & 0.152 & 0.149 & 0.008 & 0.225 & 0.144 & 0.258 \\
12 & 0.064 & 0.163 & 0.104 & 0.011 & 0.229 & 0.176 & 0.252 \\
14 & 0.065 & 0.163 & 0.105 & 0.010 & 0.230 & 0.175 & 0.253 \\
16 & 0.058 & 0.146 & 0.139 & 0.014 & 0.233 & 0.158 & 0.252 \\
\hline
\end{tabular}

Joints including parts made of different materials and screws of different diameters are evaluated with the EDAS, TOPSIS, COPRAS and SAW multiple criteria methods including generalized IDOCRIW weights. For example, Table 6 shows the results of the evaluation carried out for the joints with $8 \mathrm{~mm}$ diameter screws. 
Table 6. Comparison of screwing joints made of different materials by multiple criteria methods (case $d=8 \mathrm{~mm}$ ). EDAS: evaluation based on distance from average solution; TOPSIS: technique for order of preference by similarity to ideal solution; COPRAS: complex proportional assessment; SAW: simple additive weighting.

\begin{tabular}{|c|c|c|c|c|c|c|}
\hline Ranks & $\begin{array}{c}(\mathrm{Al}) \\
E, 7 \times 10^{4}\end{array}$ & $\begin{array}{c}(\mathrm{Stl}), \\
E, 2.1 \times 10^{5}\end{array}$ & $\begin{array}{l}\text { (Brz), } \\
E, 10^{5}\end{array}$ & $\begin{array}{c}(\mathrm{CI}) \\
E, 2.1 \times 10^{5}\end{array}$ & $\begin{array}{c}(\mathrm{Cu}) \\
E, 1.2 \times 10^{5}\end{array}$ & $\begin{array}{c}(\mathrm{Br}), \\
E, 1.2 \times 10^{5}\end{array}$ \\
\hline \multirow{2}{*}{ EDAS } & 0.524 & 0.678 & 0.145 & 0.717 & 0.444 & 0.786 \\
\hline & 4 & 3 & 6 & 2 & 5 & 1 \\
\hline \multirow{2}{*}{ TOPSIS } & 0.4862 & 0.6805 & 0.4778 & 0.6977 & 0.4490 & 0.6357 \\
\hline & 4 & 2 & 5 & 1 & 6 & 3 \\
\hline \multirow{2}{*}{ COPRAS } & 0.1416 & 0.3588 & 0.0594 & 0.1375 & 0.1458 & 0.1570 \\
\hline & 4 & 1 & 6 & 5 & 3 & 2 \\
\hline \multirow{2}{*}{ SAW } & 0.1463 & 0.2802 & 0.0695 & 0.2001 & 0.1442 & 0.1597 \\
\hline & 4 & 1 & 6 & 2 & 5 & 3 \\
\hline Sum rank & 16 & 7 & 23 & 10 & 19 & 9 \\
\hline Total rank & 4 & 1 & 6 & 3 & 5 & 2 \\
\hline
\end{tabular}

Comparing the results obtained by the different methods of multiple criteria analyses, it can be observed that, depending on the screw diameter, the joints are ranked in a different way. Generally, the first rank is attained by the Stl joint, although the EDAS method ranked the brass joint as first.

Evaluation results for the other screw diameters are presented in Table 7.

Table 7. Ranking of joints with parts made of different materials connected by 10 to $16 \mathrm{~mm}$ diameter screws (cost included) (cases $d=10,12,14,16 \mathrm{~mm}$ ).

\begin{tabular}{|c|c|c|c|c|c|c|}
\hline $\begin{array}{c}\text { Screw Diameter, } \\
d, \mathrm{~mm}\end{array}$ & $\begin{array}{c}(\mathrm{Al}) \\
E, 7 \times 10^{4}\end{array}$ & $\begin{array}{c}(\mathrm{Stl}) \\
E, 2.1 \times 10^{5}\end{array}$ & $\begin{array}{l}\text { (Brz), } \\
E, 10^{5}\end{array}$ & $\begin{array}{c}(\mathrm{CI}) \\
E, 2.1 \times 10^{5}\end{array}$ & $\begin{array}{c}(\mathrm{Cu}) \\
E, 1.2 \times 10^{5}\end{array}$ & $\begin{array}{c}\text { (Br), } \\
E, 1.2 \times 10^{5}\end{array}$ \\
\hline 10 & 4 & 1 & 6 & 3 & 5 & 2 \\
\hline 12 & 5 & 1 & 6 & $2-3$ & 4 & $2-3$ \\
\hline 14 & 5 & 1 & 6 & $2-3$ & 4 & $2-3$ \\
\hline 16 & 5 & 1 & 6 & $2-3$ & 4 & $2-3$ \\
\hline
\end{tabular}

The results show that the best variant, after incorporating the price criterion into the evaluation, appears to be Stl irrespective of the diameters of the screws. Furthermore, the worst variant is a joint made of Brz.

The average price of the material of the joint (the seventh evaluation criterion of screw) has significant influence on the evaluation. All calculations were repeated without considering the cost of the joint material criterion. Weights determined with the entropy, CILOS and IDOCRIW methods were calculated using only 6 criteria, Equations (31)-(39). The weights obtained by the IDOCRIW method are provided in Table 8.

Table 8. Weights of decision criteria determined with the IDOCRIW method (cost criterion omitted).

\begin{tabular}{ccccccc}
\hline \multirow{2}{*}{ Screw Diameter, $\boldsymbol{d}, \mathbf{m m}$} & \multicolumn{7}{c}{ Weights } \\
\cline { 2 - 7 } & $\boldsymbol{\omega}_{\mathbf{1}}$ & $\boldsymbol{\omega}_{\mathbf{2}}$ & $\boldsymbol{\omega}_{\mathbf{3}}$ & $\boldsymbol{\omega}_{\mathbf{4}}$ & $\boldsymbol{\omega}_{\mathbf{5}}$ & $\boldsymbol{\omega}_{\mathbf{6}}$ \\
\hline 8 & 0.072 & 0.212 & 0.207 & 0.009 & 0.296 & 0.204 \\
10 & 0.072 & 0.208 & 0.207 & 0.007 & 0.296 & 0.210 \\
12 & 0.072 & 0.233 & 0.135 & 0.009 & 0299 & 0.251 \\
14 & 0.072 & 0.233 & 0.136 & 0.008 & 0.301 & 0.251 \\
16 & 0.061 & 0.205 & 0.196 & 0.012 & 0.305 & 0.221 \\
\hline
\end{tabular}


Now, the EDAS, TOPSIS, COPRAS and SAW multiple criteria methods with generalized IDOCRIW weights will be applied to joints of all diameters, but omitting the price criterion. The results of such evaluation of the joints with screws of $d=8 \mathrm{~mm}$ diameter are presented in Table 9.

Table 9. Multiple criteria method-based evaluation of $8 \mathrm{~mm}$ diameter screw joints made of different materials (price omitted) $(d=8 \mathrm{~mm})$.

\begin{tabular}{|c|c|c|c|c|c|c|}
\hline Ranks & $\begin{array}{c}(\mathrm{Al}) \\
E, 7 \times 10^{4}\end{array}$ & $\begin{array}{c}(\mathrm{Stl}) \\
E, 2.1 \times 10^{5}\end{array}$ & $\begin{array}{l}\text { (Brz), } \\
E, 10^{5}\end{array}$ & $\begin{array}{c}(\mathrm{CI}) \\
E, 2.1 \times 10^{5}\end{array}$ & $\begin{array}{c}(\mathrm{Cu}) \\
E, 1.2 \times 10^{5}\end{array}$ & $\begin{array}{c}(\mathrm{Br}) \\
E, 1.2 \times 10^{5}\end{array}$ \\
\hline \multirow{2}{*}{ EDAS } & 0.303 & 0.316 & 0.210 & 0.428 & 0.807 & 0.998 \\
\hline & 5 & 4 & 6 & 3 & 2 & 1 \\
\hline \multirow{2}{*}{ TOPSIS } & 0.3815 & 0.5918 & 0.5543 & 0.5727 & 0.6752 & 0.8577 \\
\hline & 6 & 4 & 5 & 3 & 2 & 1 \\
\hline \multirow{2}{*}{ COPRAS } & 0.1719 & 0.2187 & 0.0842 & 0.1275 & 0.1897 & 0.2079 \\
\hline & 4 & 1 & 6 & 5 & 3 & 2 \\
\hline \multirow{2}{*}{ SAW } & 0.1719 & 0.2187 & 0.0842 & 0.1275 & 0.1897 & 0.2079 \\
\hline & 4 & 1 & 6 & 5 & 3 & 2 \\
\hline Sum rank & 19 & 10 & 23 & 16 & 10 & 6 \\
\hline Total rank & 5 & 3 & 6 & 4 & 2 & 1 \\
\hline
\end{tabular}

Differences between the results with the price and without the price are observed. If cost is included in the analysis, the steel joint is the best design concept, followed by brass and cast-iron joints; the bronze joint is the worst design. Conversely, if cost is not considered, the brass joint is the best design concept, followed by copper and steel joints; bronze is again the worst design. Consequently, it can be observed that a single parameter such as the price makes a considerable influence on distribution ranks of screw joints in the multiple criteria analysis. More details on triangulation tools in MCDM are given in [76].

Similarly, applying the EDAS, TOPSIS, COPRAS and SAW multiple criteria methods with generalized IDOCRIW weights joints with screws of $d=10,12,14,16 \mathrm{~mm}$, omitting the price criterion, are compared.

Table 10 presents the evaluation results for the other screw diameters of 10, 12, 14 and $16 \mathrm{~mm}$, yet without considering cost.

Table 10. Ranking of joints with parts made of different materials connected by 10 to $16 \mathrm{~mm}$ diameter screws (cost not included).

\begin{tabular}{|c|c|c|c|c|c|c|}
\hline $\begin{array}{c}\text { Screw Diameter, } \\
d, \mathrm{~mm}\end{array}$ & $\begin{array}{c}(\mathrm{Al}) \\
E, 7 \times 10^{4}\end{array}$ & $\begin{array}{c}(\mathrm{Stl}) \\
E, 2.1 \times 10^{5}\end{array}$ & $\begin{array}{l}\text { (Brz), } \\
E, 10^{5}\end{array}$ & $\begin{array}{c}(\mathrm{CI}), \\
E, 2.1 \times 10^{5}\end{array}$ & $\begin{array}{c}(\mathrm{Cu}) \\
E, 1.2 \times 10^{5}\end{array}$ & $\begin{array}{c}(\mathrm{Br}) \\
E, 1.2 \times 10^{5}\end{array}$ \\
\hline 10 & 5 & 3 & 6 & 4 & 2 & 1 \\
\hline 12 & 5 & 3 & 6 & 4 & 2 & 1 \\
\hline 14 & 5 & 3 & 6 & 4 & 2 & 1 \\
\hline 16 & $4-5$ & 3 & 6 & $4-5$ & 2 & 1 \\
\hline
\end{tabular}

Multiple criteria evaluation based only on technical parameters (i.e., regardless of cost) indicated that the best choice is to use brass joints, while the worst design is the bronze joint. If cost is included in the analysis, steel joints are the best design concept while bronze joints take again the last rank. The same conclusion was obtained by all EDAS, COPRAS and SAW methods used in the evaluation.

The results show that the price has a significant influence on the choice of the variant. A decision-maker may decide to account for cost effects or even avoid selecting joint material.

The cost of screw joints may greatly affect the global cost of a designed component. This study proved that it is possible to obtain a satisfactory solution using multiple criteria analysis of screw 
joints that encompasses both technical and economic factors. This would lead to reducing cost of the final product.

Since screw joints are used in almost all modern machines, the results obtained in this study may be very useful for the design stage of screw joints in civil and mechanical engineering.

\section{Conclusions}

Various screw joints were evaluated by MCDM methods using two sets of criteria. The first set included only technical parameters of screw joints, while in the second set, the price together with technical criteria was used.

The multiple criteria evaluation indicated that cost should have a significant impact on the selection of best screw joint.

Evaluation based on technical parameters only was carried out using four multiple criteria methods: SAW, TOPSIS, COPRAS and EDAS. It was found that the brass joint is the best choice while the worst option is the bronze joint.

If cost is included in the analysis, steel joints are the best design concept regardless of the diameter of the screw, while bronze joints are again the worst design.

The present results confirm that MCDM methods can be applied to engineering design problems including reliability and rationality aspects.

Since it was not possible to assign weights using only expert opinions, the entropy method and the more recently developed CILOS IDOCRIW methods were utilized in order to objectively assign weights to different criterions.

The proposed approach appears to be general and suited for a wide range of technical and technological problems.

Author Contributions: The individual contribution and responsibilities of the authors were as follows: A.Č. provided the research concept and the purpose and designed the research; E.K.Z. provided extensive advice throughout the study, regarding the research design, methodology, findings and revised the manuscript; A.P. collected and analyzed the data. All the authors have read and approved the final manuscript.

Funding: This research received no external funding.

Acknowledgments: We appreciate anonymous referees and the editor for their remarkable comments, deep editing suggestions, and manuscript processing.

Conflicts of Interest: The authors declare no conflict of interest.

\section{References}

1. Longqi, W.L.; Tjhen, S.; Yao, Z. Detection of loose fasteners in a third rail support assembly using a wavelet analysis. IES J. Part A Civ. Struct. Eng. 2014, 7, 73-82. [CrossRef]

2. Hester, D.; Gonzalez, A. A wavelet-based damage detection algorithm based on bridge acceleration response to a vehicle. Mech. Syst. Signal Process. 2012, 28, 145-166. [CrossRef]

3. Nguyen, K.V.; Tran, H.T. Multi-cracks detection of a beam-like structure based on the on-vehicle vibration signal and wavelet analysis. Int. J. Sound Vibr. 2010, 329, 4455-4465. [CrossRef]

4. Doyle, D.; Zagria, A.; Arritt, B.; Cakan, H. Damage detection in bolted space structures. J. Intell. Mater. Syst. Struct. 2010, 21, 251-264. [CrossRef]

5. Pal, J.; Banerjee, S.; Chikermane, S.; Banerji, P. Estimation of fixity factors of bolted joints in a steel frame structure using a vibration-based health monitoring technique. Int. J. Steel Struct. 2017, 17, 593-607. [CrossRef]

6. Jiang, X.; Zhu, Y.; Hong, J.; Chen, X.; Zhang, Y. Investigation into the loosening mechanism of bolt in curvic coupling subjected to transverse loading. Eng. Fail. Anal. 2013, 32, 360-373. [CrossRef]

7. Wentzel, H.; Huang, X.Y. Experimental characterization of the bending fatigue strength of threaded fasteners. Int. J. Fatigue 2015, 72, 102-108. [CrossRef]

8. Thanwerdas, R.; Rodriguez, E.; Daidie, A. Stiffness and slip laws for threaded fasteners subjected to a transversal load. In Advances on Mechanics, Design Engineering and Manufacturing; Springer: Cham, Switzerland, 2017; pp. 517-529. [CrossRef] 
9. Bhattacharya, A.; Sen, A.; Das, S. An investigation on the anti-loosening characteristics of threaded fasteners under vibratory conditions. Mech. Mach. Theory 2010, 45, 1215-1225. [CrossRef]

10. Milanese, A.; Marzocca, P.; Nichols, J.M.; Seaver, M.; Trickey, S.T. Modeling and detection of joint loosening using output-only broad-band vibration data. Struct. Health Monit. 2008, 7, 309-328. [CrossRef]

11. Bograd, S.; Reuss, P.; Schmidt, A.; Gaul, L.; Mayer, M. Modeling the dynamics of mechanical joints. Mech. Syst. Signal Process. 2011, 25, 2801-2826. [CrossRef]

12. Esmaeel, R.A.; Briand, J.; Taheri, F. Computational simulation and experimental verification of a new vibration-based structural health monitoring approach using piezoelectric sensors. Struct. Health Monit. 2012, 11, 237-250. [CrossRef]

13. Zhao, Y.; Yang, C.; Cai, L.; Shi, W.; Hong, Y. Stiffness and damping model of bolted joints with uneven surface contact pressure distribution. Strojniski Vestnik J. Mech. Eng. 2016, 62, 665-677. [CrossRef]

14. Dinger, G.; Friedrich, C. Avoiding self-loosening failure of bolted joints with numerical assessment of local contact state. Eng. Fail. Anal. 2011, 18, 2188-2200. [CrossRef]

15. Zapico-Valle, J.L.; Garcia-Dieguez, M.; Gonzalez-Martinez, P.; Worden, K. Experimental validation of a new statistical process control feature for damage detection. Mech. Syst. Signal Process. 2011, 25, 2513-2525. [CrossRef]

16. An, Y.K.; Sohn, H. Integrated impedance and guided wave based damage detection. Mech. Syst. Signal Process. 2012, 28, 50-62. [CrossRef]

17. Zhu, W.D.; He, K. Detection of damage in space frame structures with 1-shaped beams and bolted joints using changes in natural frequencies. J. Vibr. Acoust. Trans. ASME 2013, 135, 263-289. [CrossRef]

18. Huda, F.; Kajiwara, I.; Hosoya, N.; Kawamura, S. Bolt loosening analysis and diagnosis by non-contact laser excitation vibration tests. Mech. Syst. Signal Process. 2013, 40, 589-604. [CrossRef]

19. Kajiwara, I.; Hosoya, N. Vibration testing based on impulse response excited by laser ablation. J. Sound Vibr. 2011, 330, 5045-5057. [CrossRef]

20. Hosoya, N.; Kajiwara, I.; Hosokawa, T. Vibration testing based on impulse response excited by pulsed-laser ablation: Measurement of frequency response function with detection-free input. J. Sound Vibr. 2012, 331, 1355-1365. [CrossRef]

21. Izumi, S.; Yokoyama, T.; Kimura, M.; Sakai, S. Loosening-resistance evaluation of double-nut tightening method and spring washer by three-dimensional finite element analysis. Eng. Fail. Anal. 2009, 16, 1510-1519. [CrossRef]

22. Yokoyama, T.; Oishi, K.; Kimura, M.; Izumi, S.; Sakai, S. Evaluation of loosening resistance performance of conical spring washer by three-dimensional finite element analysis. J. Solid Mech. Mater. Eng. 2008, 2, $38-46$. [CrossRef]

23. Ramadan, A.E.; Taheri, F. Application of a simple and cost-effective method for detection of bolt self-loosening in single lap joints. Nondestruct. Test. Eval. 2013, 28, 208-225. [CrossRef]

24. Argatov, I.; Sevostianov, I. Health monitoring of bolted joints via electrical conductivity measurements. Int. J. Eng. Sci. 2010, 48, 874-887. [CrossRef]

25. Croccolo, D.; DeAgostinis, M.; Vincenzi, N. Influence of tightening procedures and lubrication conditions on titanium screw joints for light weight applications. Tribol. Int. 2012, 55, 68-76. [CrossRef]

26. Yokoyama, T.; Olsson, M.; Izumi, S.; Sakai, S. Investigation into the self-loosening behavior of bolted joint subjected to rotational loading. Eng. Fail. Anal. 2012, 23, 35-43. [CrossRef]

27. Lim, H.J.; Kim, M.K.; Sohn, H.; Park, C.Y. Impedance based damage detection under varying temperature and loading conditions. NDT E Int. 2011, 44, 740-750. [CrossRef]

28. Nah, H.S.; Choi, S.M. Estimation on clamping load of high strength bolts considering various environment conditions. Steel Compos. Struct. 2017, 24, 399-408. [CrossRef]

29. Croccolo, D.; DeAgostinis, M.; Vincenzi, N. Failure analysis of bolted joints effect of friction coefficients in torque-preloading relationship. Eng. Fail. Anal. 2010, 18, 364-373. [CrossRef]

30. Sánchez Egea, A.J.; Deferrari, N.; Abate, G.; Martínez Krahmer, D.; de Lacalle, L.N.L. Short-cut method to assess a gross available energy in a medium-load screw friction press. Metals 2018, 8, 173. [CrossRef]

31. Landeta, J.F.; Valdivielso, A.F.; de Lacalle, L.N.L.; Girot, F.; Pérez, J.M.P. Wear of form taps in threading of steel cold forged parts. J. Manuf. Sci. Eng. Trans. ASME 2015, 137, 031002. [CrossRef]

32. Elosegui, I.; Alonso, U.; de Lacalle, L.N.L. PVD coatings for thread tapping of austempered ductile iron. Int. J. Adv. Manuf. Technol. 2017, 91, 2663-2672. [CrossRef] 
33. Morozov, A.V. Experimental estimate of tribological characteristics of epilam-coated materials that operate in threaded joints under dry friction. J. Frict. Wear 2014, 35, 170-176. [CrossRef]

34. Solis, M.; Algaba, M.; Galvin, P. Continuous wavelet analysis of mode shapes differences for damage detection. Mech. Syst. Signal Process. 2013, 40, 645-666. [CrossRef]

35. Čereška, A.; Podvezko, V.; Zavadskas, E.K. Operating characteristics analysis of rotor systems using MCDM methods. Stud. Inform. Control 2016, 25, 59-68. [CrossRef]

36. Čereška, A.; Zavadskas, E.K.; Cavallaro, F.; Podvezko, V.; Tetsman, I.; Grinbergienè, I. Sustainable assessment of aerosol pollution decrease applying multiple attribute decision-making methods. Sustainability 2016, 8, 586. [CrossRef]

37. Čereška, A.; Bučinskas, V.; Zavadskas, E.K.; Podvezko, V.; Šutinys, E. Analysis of steelwire rope diagnostic data applying multi-criteria methods. Appl. Sci. 2018, 8, 260. [CrossRef]

38. Zavadskas, E.K.; Antucheviciene, J.; Turskis, Z.; Adeli, H. Hybrid multiple-criteria decision-making methods: A review of applications in engineering. Sci. Iran. 2016, 23, 1-20.

39. Zavadskas, E.K.; Antucheviciene, J.; Hajiagha, S.H.R.; Hashemi, S.S. The interval-valued intuitionistic Fuzzy MULTIMOORA method for group decision making in engineering. Math. Probl. Eng. 2015, 2015, 1-13. [CrossRef]

40. NakhaeI, J.; Bitarafan, M.; Arefi, S.L.; Kaplinski, O. Model for rapid assessment of vulnerability of office buildings to blast using SWARA and SMART methods (a case study of Swiss re tower). J. Civ. Eng. Manag. 2016, 22, 831-843. [CrossRef]

41. Rashidi, M.; Ghodrat, M.; Samali, B.; Kendall, B.; Zhang, C.W. Remedial modelling of steel bridges through application of analytical hierarchy process (AHP). Appl. Sci. 2017, 7, 168. [CrossRef]

42. Souzangarzadeh, H.; Rezvani, M.L.; Jahan, A. Selection of optimum design for conical segmented aluminum tubes as energy absorbers: Application of MULTIMOORA method. Appl. Math. Model. 2017, 51, 546-560. [CrossRef]

43. Terracciano, G.; Di Lorenzo, G.; Formisano, A.; Landolfo, R. Cold-formed thin-walled steel structures as vertical addition and energetic retrofitting systems of existing masonry buildings. Eur. J. Environ. Civ. Eng. 2015, 19, 850-866. [CrossRef]

44. Bučmys, A.; Daniūnas, A. Rectangular gusset plate behaviour in cold-formed I-type steel connections. Arch. Civ. Eng. 2017, 63, 3-21. [CrossRef]

45. Shahriar, A.; Modirzadeh, M.; Sadiq, R.; Tesfamariam, S. Seismic induced damageability evaluation of steel buildings: A Fuzzy-TOPSIS method. Earthq. Struct. 2012, 3, 695-717. [CrossRef]

46. Sanchez-Lozano, J.M.; Meseguer-Valdenebro, J.L.; Portoles, A. Assessment of arc welding process through the combination of TOPSIS-AHP methods with fuzzy logic. Trans. Indian Inst. Met. 2017, 70, 935-946. [CrossRef]

47. Madic, M.; Antucheviciene, J.; Radovanovic, M.; Petkovic, D. Determination of laser cutting process conditions using the preference selection index method. Opt. Laser Technol. 2017, 89, 214-220. [CrossRef]

48. Yin, H.F.; Xiao, Y.Y.; Wen, G.L.; Qing, Q.X.; Deng, Y.F. Multi objective optimization for foam-filled multi-cell thin-walled structures under lateral impact. Thin-Walled Struct. 2015, 94, 1-12. [CrossRef]

49. Fang, J.G.; Gao, Y.K.; Sun, G.Y.; Qiu, N.; Li, Q. On design of multi-cell tubes under axial and oblique impact loads. Thin-Walled Struct. 2015, 95, 115-126. [CrossRef]

50. Rezvani, M.J.; Jahan, A. Effect of initiator, design, and material on crashworthiness performance of thin-walled cylindrical tubes: A primary multi-criteria analysis in lightweight design. Thin-Walled Struct. 2015, 96, 169-182. [CrossRef]

51. Pirmohammad, S.; Marzdashti, S.E. Crushing behavior of new designed multi-cell members subjected to axial and oblique quasi-static loads. Thin-Walled Struct. 2016, 108, 291-304. [CrossRef]

52. Zheng, G.; Wu, S.Z.; Sun, G.Y.; Li, G.Y.; Li, Q. Crushing analysis of foam-filled single and bitubal polygonal thin-walled tubes. Int. J. Mech. Sci. 2014, 87, 226-240. [CrossRef]

53. Qiu, N.; Gao, Y.K.; Fang, J.G.; Feng, Z.X.; Sun, G.Y.; Li, Q. Crashworthiness analysis and design of multi-cell hexagonal columns under multiple loading cases. Finite Elem. Anal. Des. 2015, 104, 89-101. [CrossRef]

54. Esmaeili-Marzdashti, S.; Pirmohammad, S. Crashworthiness analysis of s-shaped structures under axial impact loading. Lat. Am. J. Solids Struct. 2017, 14, 743-764. [CrossRef]

55. Bitarafan, M.; Hashemkhani Zolfani, S.; Arefi, S.L.; Zavadskas, E.K. Evaluating the construction methods of cold-formed steel structures in reconstructing the areas damaged in natural crises, using the methods AHP and COPRAS-G. Arch. Civ. Mech. Eng. 2012, 12, 360-367. [CrossRef] 
56. Maity, S.R.; Chatterjee, P.; Chakraborty, S. Cutting tool material selection using grey complex proportional assessment method. Mater. Des. 2012, 36, 372-378. [CrossRef]

57. Chatterjee, P.; Athawale, V.M.; Chakraborty, S. Materials selection using complex proportional assessment and evaluation of mixed data methods. Mater. Des. 2011, 32, 851-860. [CrossRef]

58. Chatterjee, P.; Chakraborty, S. Material selection using preferential ranking methods. Mater. Des. 2012, 35, 384-393. [CrossRef]

59. Mousavi-Nasab, S.H.; Sotoudeh-Anvari, A. A comprehensive MCDM-based approach using TOPSIS, COPRAS and DEA as an auxiliary tool for material selection problems. Mater. Des. 2017, 121, 237-253. [CrossRef]

60. Yazdani, M.; Jahan, A.; Zavadskas, E.K. Analysis in material selection: Influence of normalization tools on COPRAS-G. Econ. Comput. Econ. Cybern. Stud. Res. 2017, 51, 59-74.

61. Nguyen, H.T.; Dawal, S.Z.M.; Nukman, Y.; Aoyama, H.; Case, K. An integrated approach of fuzzy linguistic preference based AHP and Fuzzy COPRAS for machine tool evaluation. PLoS ONE 2015, 10, 1-24. [CrossRef] [PubMed]

62. Dupen, B. Applied Strength of Materials for Engineering Technology; Purdue University: West Lafayette, IN, USA, 2012.

63. Keshavarz Ghorabaee, M.; Zavadskas, E.K.; Olfat, L.; Turskis, Z. Multi-criteria inventory classification using a new method of evaluation based on distance from average solution (EDAS). Informatica 2015, 26, 435-451. [CrossRef]

64. Hwang, C.L.; Yoon, K. Multiple Attribute Decision Making Methods and Applications: A State of the Art Survey; Springer: Berlin, Germany, 1981.

65. Zavadskas, E.K.; Kaklauskas, A.; Šarka, V. The new method of multi-criteria complex proportional assessment of projects. Technol. Econ. Dev. Econ. 1994, 1, 131-139.

66. Zavadskas, E.K.; Podvezko, V. Integrated determination of objective criteria weights in MCDM. Int. J. Inf. Technol. Decis. Mak. 2016, 15, 267-283. [CrossRef]

67. Podviezko, A.; Podvezko, V. Influence of data transformation on multicriteria evaluation result. Procedia Eng. 2015, 122, 151-157. [CrossRef]

68. Jakimavicius, M.; Burinskiene, M.; Gusaroviene, M.; Podviezko, A. Assessing multiple criteria for rapid bus routes in the public transport system in Vilnius. Public Transp. 2016, 8, 365-385. [CrossRef]

69. Palevicius, V.; Sivilevicius, H.; Podviezko, A.; Griskeviciute-Geciene, A.; Karpavicius, T. Evaluation of park and ride facilities at communication corridors in a middle-sized city. Econ. Comput. Econ. Cybern. Stud. Res. 2017, 51, 231-248.

70. Palevicius, V.; Grigonis, V.; Podviezko, A.; Barauskaite, G. Developmental analysis of park-and-ride facilities in Vilnius. PROMET-Traffic Transp. 2016, 28, 165-178. [CrossRef]

71. Podviezko, A.; Podvezko, V. Absolute and relative evaluation of socio-economic objects based on multiple criteria decision making methods. Eng. Econ. 2014, 25, 522-529. [CrossRef]

72. Shannon, C.E. A mathematical theory of communication. Bell Syst. Tech. J. 1948, 27, 379-423, $623-656$. [CrossRef]

73. Mirkin, B.G. Group Choice; Winston \& Sons: Washington, DC, USA, 1979.

74. Ma, J.Z.; Fan, P.; Huang, L.H. A subjective and objective integrated approach to determine attribute weights. Eur. J. Oper. Res. 1999, 112, 397-404. [CrossRef]

75. Parfenova, L.; Pugachev, A.; Podviezko, A. Comparative analysis of tax capacity in regions of Russia. Technol. Econ. Dev. Econ. 2016, 22, 905-925. [CrossRef]

76. Podviezko, A. Augmenting multicriteria decision aid methods by graphical and analytical reporting tools. In International Conference on Business Informatics Research; Niedrite, L., Strazdina, R., Wangler, B., Eds.; Lecture Notes in Business Information Processing; Springer: Berlin/Heidelberg, Germany, 2012; Volume 106, pp. 236-251. [CrossRef]

(C) 2018 by the authors. Licensee MDPI, Basel, Switzerland. This article is an open access article distributed under the terms and conditions of the Creative Commons Attribution (CC BY) license (http:/ / creativecommons.org/licenses/by/4.0/). 